\title{
Фразеология и магические практики в контексте антропо- и космогонических легенд (белорусская традиция на европейском фоно)
}

\section{Татьяна Володина}

Центр исследований белорусской культуры, языка и литературы Национальной академии наук Беларуси tanja_volodina@tut.by

\begin{abstract}
Аннотация: На протяжении последних двух столетий антропогонические легенды стабильно удерживают к себе внимание в европейской фрольклористике. Довольно подробно изучен общий фронд мотивов, сопоставлены архаические и библейские элементы, описаны отдельные сюжеты и образы. Вместе с тем каждая этническая традиция входит в общий фонд своими порой уникальными вариантами, которые не просто обогащают целое, но и позволяют по-новому взглянуть на уже привычное, полнее и глубже реконструировать корни явлений и описать актуальное состояние. Полевые записи последних лет, сделанные в Беларуси после более полувека угасшего интереса к данной тематике, демонстрируют богатство представлений сферы антропогонии и даже новые как сюжеты, так и отдельные детали. Сюжеты народной Библии становятся мировоззренческим фроном и служат источником для ряда устойчивых языковых единиц, а также для заговоров и представлений сферы народной медицины. В статье рассматриваются мотивы создания Евы из хвоста Адама, роговой кожи перволюдей, утаивания антагонистом земли за ногтями при миротворении и их репрезентации в паремиологическом фонде языков.
\end{abstract}


Ключевые слова: фрразеология, антропогония, космогония, легенды, белорусский фольклор, народная Библия, библеизмы, народная медицина, заговоры

В современной гуманитаристике уже аксиоматичным является утверждение о едином поле смыслов для фольклорных текстов, ритуальных практик и устойчивых выражений языка той или иной этнической (или, шире, региональной) культуры. Назовем мы әто поле картиной (моделью) мира или же когнитивным пространством, сути это не изменит. Не требует доказательств и то, что самым богатым источником идиоматики является Библия. В последние десятилетия библейские тексты и библейские фразеологизмы изучаются весьма активно, обычно они рассматриваются в работах о происхождении и источниках фразеологии, лексико-фразеологических заимствованиях, об архаических формах, фрункционировании библейской фрразеологии в художественной литературе, современной речи, активно осуществляется сопоставление библеизмов в славянских и западноевропейских языках. Глубокие исследования представлены и на материале эстонского языка ${ }^{1}$.

Подавляющее большинство библейских фрразеологизмов относится к разряду фразеологизмов книжных, однако во всех языках встречаются фрразы, образованные на основе соответствующих сюжетов, см. к примеру в костюле Адала, посылать кого-л. от Понтия к Пилату. "Такие афоризмы и выражения по терминологии проф. Х. Вальтера названы «косвенными библеизмами». Аргументом в пользу зачисления их к разряду библеизмов явилась тесная связь с библейским текстом и возможность комментирования их внутренней формы именно на этой основе» (Мокиенко 2013: 149). Так, оборот Адамово яблоко (нем. Adamsapfel, в 1678 г. зафиксированное в варианте Adamsbissen (Höfler 1899: 43) как таковой в Библии не встречается, хотя его значение мотивировано народно-поэтическим осмыслением ветхозаветного сюжета: часть запретного плода (кусок яблока, данного ему Евой) застряла в горле Адама. В словаре белорусского языка И. Носовича выражение так и объясняется: Адамово яблоко 'передняя горловая выдающаяся косточка, у многих 
мужчин очень заметная. Есть поверье, что от проглоченного Адамом запретного плода' (Носович 1870: 3$)^{2}$.

Подобную историю охотно пересказывают до настоящего времени в белорусских (и не только) деревнях:

Адам і Ева нарадзіліся... Не трэба было плод той есці! Я не знаю, які плод, сліва ці што... А ён узяў, ды не ўправіўся пракаўтнуць. Дак за тое ў яго тут «яблачка» [паказвае на шыю]. Ева пракаўтнула, а Адам не. (смяещца). Эта былі святыя, а так саграшылі ${ }^{3}$

Адам і Ева сядзелі дзе-та ў саду. I яблына там была. А Ісус Хрыстос 4 сказаў ім:

- Ня ешце яблыка!

А яны ж ня вытрымалі. Ева вытрымала, а Адам не, і ўкусіў.

А Ён ім:

- Ну што, ня вытрымаў?

А яно сперачылася яму ў горле. Цяпер і костачка ў яго тут. Раз ён з'еў.

- А Ева не ела?

- А Ева ня ела. Вот у яе і няма 5 .

Любопытны переосмысления участия в этом эпизоде Евы.

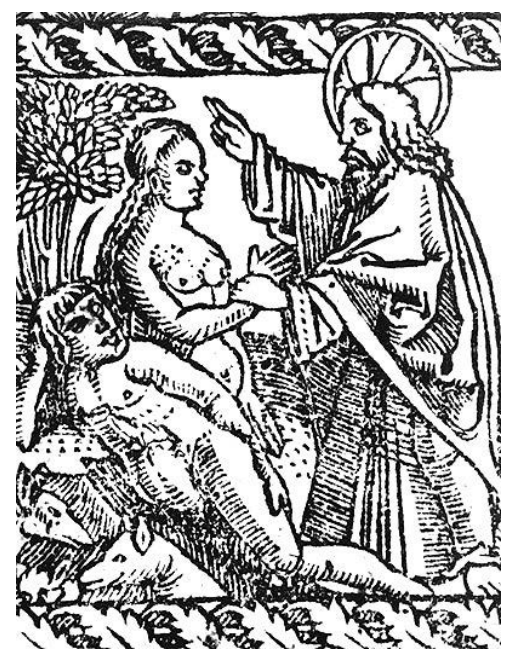

Адам и Ева в книге Бытия (1519), гравюра Ф. Скорины. 
Сюжет и само выражение Адамово яблоко известны многим европейским языкам - ср. лат. poтum Adami, англ. Adam's apple; dpp. pomme (le morceau) d'Adam; ит. pomo d'Adamo и мн. др., живы в народных пересказах и легендах, что ставит под сомнение идею о его калькировании в русском (славянских) языках (Walter \& Mokienko 2009: 28). Ф. Клюге предполагает в данном случае реинтерпретацию еврейского tappuach $h a$ adam = pomum viri (Kluge 1899: 4).

Этиологические легенды подобного рода (с вариантом, кто первым откусил от яблока) входят в состав так называемой народной Библии. Прихожане, прежде всего деревенские, мировоззрение которых органически сочетало как христианские, так и дохристианские элементы, во время службы в храмах слушали, воспринимали канонические и апокрифические сюжеты, и услышанное закономерно объединялось с архаическими воззрениями. Многочисленные «цитаты» из славянской средневековой книжной традиции, где были широко распространены сюжеты, взятые из Библии или византийских апокрифов ${ }^{6}$, проходили таким образом фольклорную обработку в контексте традиционной картины мира. Народные легенды на темы Ветхого и Нового Завета, а также поверья и приметы, связанные с фольклорными «библейскими» нарративами, сегодня наглядно демонстрируют нам, что услышанные, прочитанные версии «перерабатываются и интерпретируются народной традицией в соответствии со стереотипами фольклорно-мифологического сознания» (Белова 2004: 18). Многое из того, что лингвисты назвали «косвенными библеизмами», фольклористы давно и устойчиво именуют народнобиблейскими мотивами и образами.

Осмысление событий «священной истории» в повседневной жизни традиционного общества находит конкретное воплощение не только собственно в цитатах, пусть и “косвенных", но и в системе актуальных верований, заговоров, примет и связанных с ними ритуально-магических практик.

Белорусские заговоры, вербально реализуя архаические космологические схемы, к антропогоническим мотивам обращаются реже, однако зафиксированные тексты в целом являются наглядной иллюстрацией фонкционирования библейской цитаты в традиционной духовной культуре. Так, заговорные образы Адама и Евы могут включаться в прецедентные ситуации, к примеру, в заговоре от головной боли представлена 
Гравюра Ф. Скорины из «Малой подорожной книжки» (Вильно, 1522).

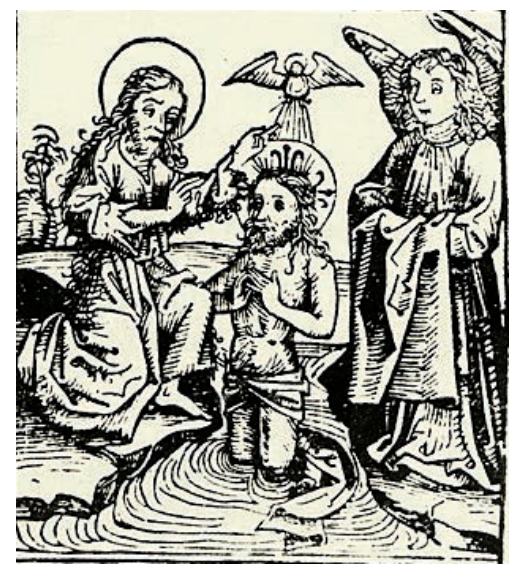

цепочка передач, аккумулировавшая в себе обратную «библейскую историю»: «У Адама баліць галава, Адам перадаў боль Еве, Ева - змяе, змяя - д’яблу, д’ябал - сонцу, сонца - мору, мора - ветру і вецер развеяў» ${ }^{7}$. С Адамом как первочеловеком символически соотносится больной, неслучайна и акцентация головы Адама, мотив которой отличается широтой экспликации на уровне вторичных номинаций. Источником здесь является библейско-христианское представление о покоящихся в основании горы Голгофы останках Адама, повлекшее за собой иконографический мотив - изображение черепа и костей под основанием креста в сюжете «Распятие» (Родионова 2000: 123). Частотен мотив беседы с мертвым телом Адама в целительных фрункциях, преимущественно при лечении зубной боли; в заговорах упоминаются и Адамовы дети: «от зубной боли становятся лицом к молодому месяцу, тремя пальцами делают круг по солнцу вокруг зубов и произносят: “Святы месяи па небу лятаў, Адаливььх дзяией відаў. У Адалавьх дзяией ні зубь, ні губь не балелі, ні косткі ні ламілі. Дьк і уумяне, рабы Божай (імя), ні губь, ні зубы не баляць, ні косиі не ломяць. Ва векі вякоў. Aлиінь» ${ }^{8}$. Адам и Ева упоминаются как начало всего. Кроме такого прецедентного статуса образы перволюдей в заговорах выступают наряду с иными сакральными помощниками в типичных сюжетных ситуациях: 
Паехаў Адам на зялезных калёсах, паўёз урокі, падуманьні, згаворы па ўсіх сёлах. Папоўскія, парабоўскія, панскія, цыганскія, татарскія, жыдоўскія, французскія, германскія, аўстрэйскія, мышкавы, жабкавы, ужовы і камарковы; Перэход, перэход, сколькі цебе год? Казаў Адам і Ева, што ты тут не трэба. Пошлі дзеткі у сад, грушок-яблычкі зьбіраць, ды перэходу ў рабы Божое (імя) вовек не бываць ${ }^{10}$.

Среди разнообразных славянских ритуалов, связанных с магией имени, именования, переименования, зова по имени и т.д., известны магические приемы присвоения имен Адам и Ева «опасным» для человека существам и духам - мертворожденным или умершим до крещения детям (Толстая 1998: 34). В Западной Беларуси считалось необходимым, услышав плач ребенка, тотчас же спросить: «Божья душечка, что тебе нужно?» И если она ответит: «Святого креста», то следует сделать рукой знак креста и дать имя Адам или Ева, тогда голос тотчас же стихнет (Federowski 1897: № 1343). Так же надо было поступать при встрече с нечистой силой. В верованиях, некрещеный умерший младенец пугает, появляясь ночью перед пастухами и выходя к костру, тогда нужно перекрестить и сказать: «Если ты мальчик, будь Адам. А если девочка - Евой» ${ }^{11}$. До недавнего времени действенным считалось называние ребенка именем Адама или Евы в том случае, если до этого в семье умирали дети. Обет назвать таким именем ребенка дала наша информантка Швед Н. А., которая долго не могла забеременеть:

У мене дачка Ева і сын Адам і сын Петро. Я доўго не рожала дзецей, а тады родзіла. Еслі я рожу, будзе дзеўка, назову Ева, оброк такі дала, а еслі будзе хлопец, будзе Адам. - [А вы дзе гәты аброк давалі. У царкву хадзілі?] - Сама собе, сама собе. Думаю, еслі только вот родзіщца дзевочка, будзе Ева. Родзіласа дзеўка, назвала Ева. Цераз тры, на чацвертом году хлопец родзіўса, назвалі Адамом, а потым хлопец родзіўса перад Петром. Назвала его Петром. Усе с'ятые ${ }^{12}$.

Белорусские антропогонические легенды содержат весьма любопытные детали, представляющие собой своеобразную трансформацию библейского сюжета о первых людях (Быт. гл. 1-5). Прежде всего объяснению и интерпретации подверглись наиболее близкие и «приземленные» особенности священных событий. К примеру, внешний облик первых людей до грехопадения. Адам и Ева изображаются подчеркнуто нагими, достаточно 


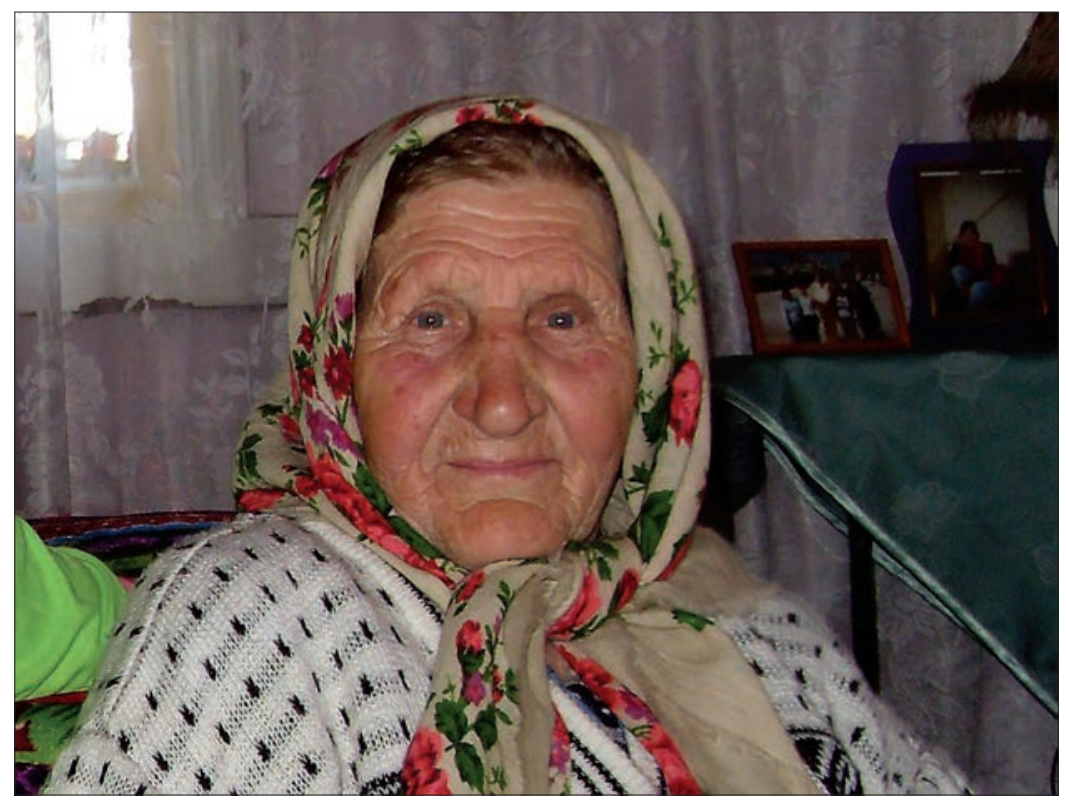

Надежда Швед. Фото Т. Володиной.

вспомнить один из самых популярных библеизмов гол (голый) как Адали или в костюле Адали. «По частотности употребления и количеству производных сема наготы, пожалуй, наиболее продуктивна как в славянских, так и других европейских языках» (Мокиенко 1998: 21).

Многочисленные «цитаты» из славянской средневековой книжной традиции, где были широко распространенны сюжеты, взятые из Библии или византийских апокрифов ${ }^{13}$, прошли фольклорную обработку в контексте традиционной картины мира. Исследователи обращают внимание и на ряд очень близких параллелей или даже совпадений между славянской и еврейской традициями ${ }^{14}$, учитывая при этом исторические факты, свидетельствующие о многовековом соседстве белорусов и евреев и высокой степени межконфессиональной толерантности в традиционном белорусском обществе. Если говорить о белорусско-еврейских параллелях в области народной библей- 
ской антропогонии, то это первоначальная нерасчлененность мужчины и женщины, некоторое сходство основных мотивов творения Евы (неоднократность ее творения, создание женщины из хвоста). Согласно белорусским легендам, Бог создал Адама с хвостом, но чтобы отделить его от животного мира, отрезал этот хвост и сделал из него женщину:

Буог як створыў Адама, то створыў его з хвастом; посля Буог апамятаўся, што кепско гэтак каб усе - і жывіна, і людзі былі з хвастамі, так навярнуў на Адама сон і адрэзаў ему хвуост і палажыў кала его і зрабіласе з таго хваста жуонка Ева. То кабеты паходзяць з мужчынскага хваста (Federowski 1897: 201)15.

Першаго чалавека Бог сатварыў з хвастом, як іншыя стварэння. Куды ні ідзе чалавек, а хвост цягнецца ззаду. Сустракае раз чалавека шатан да й пытае яго, нашто яму хвост. Не ведае чалавек, што атказаць, нашто яму хвост, да кажэ, што так яму Бог даў. Ці доўго, ці не, не ведаў чалавек, навошта ў яго хвост, як ось бачыць, што з яго хваста вырасла жанчына (Сержпутоўскі 1998: 62).

В белорусской легенде, записанной в Даугавпилском уезде Латвии, рассказывается, когда Бог достал из Адама ребро, мокрое и в крови, чтоб создавать из него женщину, то решил его подсушить. Но в это время появилась собака, ухватила ребро и понесла. Ангелы гонялись за ней, гонялись, наконец младший ухватил хвост и принес Богу. "Хоць $і$ не такая выйдзе як трэба, усё ж на бабу будзе пахожа, бо тут ёсьиь $і$ костка, $і$ мяса, $і$ шэрсьиь». А байку свою рассказчик завершил так: "Ну угледзісь, з чаго баба, калі ні з хваста» ${ }^{16}$. Падобная этой русская легенда завершается суждением, что «Оттого, говорять, у бабы на кончике языка держатся миьсли, оттого она и любит “брехать”. «Если в раввинистических текстах этот сюжет про хвост возникает при попытке проинтерпретировать разные значения слова gkm, встречающегося в Библии, то в славянском фольклоре он бытует как самостоятельный сюжет» (Каспина). Следует заметить, что в Талмуде слово со значением 'ребро' называет и хвост, откуда и могла произойти такая вариантность (Григорьев 2006: 51). Легенда может послужить иллюстрацией для корреляций оппозиций мужчина/женщина и культура/природа, когда подчеркивается близость женского к миру природы, т.к. хвост не присущ человеку. На уровне языка см. лемкивскую поговорку зоз пшячого хвоста створеный 'недотепа' (Вархол \& Івченко 1990: 137). 


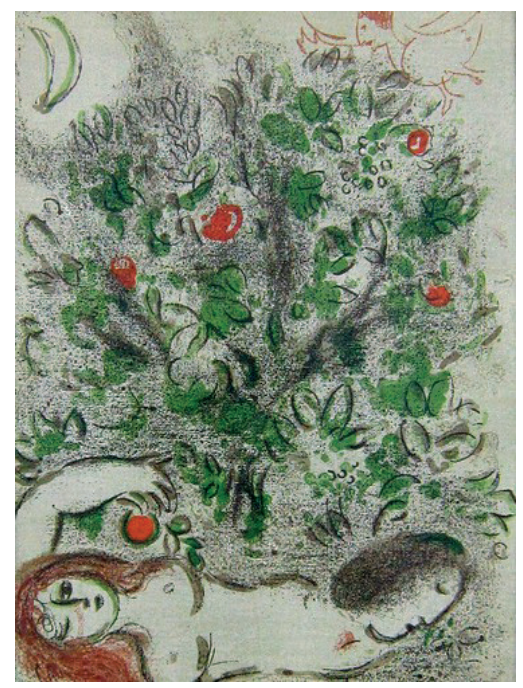

Марк Шагал. Адам и Ева под запретным деревом.

Для фонкционирования библейских прецедентных текстов в народной традиции характерна тенденция вхождения текста в сореру активных верований, когда они выступают как комментарий к обрядовым действиям или, чаще, объяснение какой-то закономерности. К примеру, мотив создания Евы из левого ребра Адама подчеркивает хтоническую сущность женщины и более высокий статус мужчины - «Эта мая иётка казала: "Мужчына - свянцоная костачка". Наверна, што Бог саздаў, а тады з яго рабра Еву. "Вы глядзіия, не абіжайия мужчын, эта ж свянионая костачка" ${ }^{17}$ и объясняет, почему некоторые из мужчин никогда не женятся: «Бог зрабіу свет за шэсиь дней. Узяў з зяллі зляпіу чалавека, Адала першага. А Еву здзелаў з рабра, узяў у Адала рабро, $і$ жану ялу здзелаў. Вот і няла $\check{y}$ мужчьн рабра, а у каторага ўсе робры - будзе нежанаты» ${ }^{18}$. Отношения первой пары проецируются в свет любовных отношений и как неоспоримый фракт входят в текст приворота: "Адал і Ева саграшылі, дзящей нарадзілі, друг друга палюбілі i тыл мяне палюбі» ${ }^{19}$. 
Устойчив и мотив роговой оболочки, покрывавшей тело прародителей до грехопадения. Такое ногтевое тело было практичнее, защищало от холода.

Прежда у Адама и у Евы была тела кожаная, якъ ногыть, а какъ сагряшили яны, то снялась ета кожа, - и стали яны стыдъ иметь ... Тела ихъ стала другоя: то адияния ихъ была, якъ ногать на руке, а то адияния ета так и объехала - застались толька ногтики на пальцах на руках и на ногах, - и стали люди голы и стали стыд иметь... (Добровольский 1831: 236, 240).

У Адама і Евы шкура была такая, як у нас ногці, але як яны заграшыли і Бог іх выгнаў з раю, то тая скура аблезла з іх, анно ў канцы пальцаў засталася (Federowski 1897: 201).

Цело ў людзей было адзето цьвордаю шкарупаю й нічого не баяласо. Як людзі саграшылі, дык тая шкарупа прапала, толькі трохі засталосо на канцох палцаў, каб людзі не забылі, як калісь жылі (Сержпутоўскі 1998: 62).

Мотив ногтевого тела фриксируется и у соседей - в русской, украинской, польской и литовской традициях:

pус. Адамово тело все было очень чисто и красиво. Кожа его у нас только на руках: ногти. У Адама было все тело покрыто сплошь ногтем. И поэтому ему жилось хорошо: его ни блохи, ни мухи, никакая шутова тварь не трогали. Ну вот. Как Бог выгнал его из рая, то его шкура сменилась, а уж у его детей осталось только на концах пальцев - и то по просьбе Адама. Адам обратился к Богу и говорит: Господи! Оставь ты хоть на память кожи живой и вечной у детей моих в память меня. ... И Бог послушал Адама и оставил на пальцах коймы - завем ногти Саратов. (Белова \& Кабакова 2014: 235-236 и далее примеры);

пол. Stworzone odzienie dla Adama było nieśmiertelne: włosy $i$ paznogcie obrastały całe ciało...Вильнюc. Pierwsi ludzie byli tadni, ale ich ciało nie było takie jak nasze, jak teraz, ale było jak paznokieć...to tylko ten paznokieć został na pamiątkę, że to takie byli Adam i Ewa. Пшемысль. (Zowczak 2013: 97, еще примеры из польской традиции Fischer 1909: 326, литовской Кербелите 2001:107, см. также Dahnhardt 1907: 226).

См. также у сету в Эстонии: Бог первым создал Адама (и пустил его в рай). Адам гулял по саду один и скучал. Тогда Бог положил его спать, и из левой стороны взял ребро, отломал от него кусочек и сделал Еву. И Бог разрешил им есть все в саду, 
кроме того, что растет на одном дереве. Адаму и Еве не нужна была одежда, потому что все тело у них было как ногти. Наши ногти - это воспоминание о тех первых людях ${ }^{20}$.

Мотив «ногтевого» тела («кожаной одежи») перекликается с упоминанием в Библии кожаных одежд, в которые Адама и Еву облачил Бог перед изгнанием их из рая (Быт 3: 21).

В этом контексте объяснимо особое отношение к ногтям, которые стали истолковываться как «воспоминание о первоначальном облике человека, таком, как его создал Господь, и, следовательно, о потерянном совершенстве» (Кабакова 2001: 30), что наряду с наивно-анатомическими представлениями регламентирует их обрезание и последующее с ними обращение. Даже детей наказывали за то, что грызли ногти, иначе они «згрызаюць сваё шчасце» (Васілевіч \& Салавей 2009: 51). «Да, дзеці, эта казала мая прабаба, што у празьнік нельзя абразаць нагцей. Эта на сьвятых людзей такая кожа, як у нас ногці. Эта бальшы грэх. За ўсё грэх, а большы грэх за ўсяго, еслі ў празнік абразаеш ногці» ${ }^{15}$. Разбрасывать остриженные ногти строго воспрещалось, считалось, что они будут нужны человеку после смерти. У восточных славян, особенно у старообрядцев, было принято собирать ногти в специальный мешочек (иногда - в перстень), а после смерти класть в гроб. Считалось, что на тот свет, в рай нужно будет лезть по высокой стеклянной или железной горе, и сделать это будет легче тому, у кого при себе окажутся ногти, которые после смерти прирастут к пальцам; по другой версии, остриженные ногти пригодятся после Страшного суда при воскресении всех умерших, которые будут этими ногтями разгребать свои могилы (ю.-рус.) (Левкиевская 2004: 427).

В белорусском Поднепровье сохранились показательные тексты апотропейного содержания ногтей, однако данная семантика напрямую увязывается с антропогоническим сюжетом. Еще более любопытно то, что для наименования ногтей используется устойчивое метафорическое выражение адамава кожа/ цела. Для предохранения от сглаза рекомендовалось провести ногтем по бровям и сказать:

Нада ногцем правесьці над бравямі і сказаць: «Адамава кожа, сахрані мяне Божа, ад чорных бравей да белых ног». Эта за сталом. Скажы, і пі і гуляй і еш, і нічога не прыстанець. I як прыдзеш на гулянку якую, і там народу многа, і ты прэкрасна выглядзіш, каб не зглазілі, нада так пальцы злажыць, адну руку 
і втарую, кулачкамі, і сматрэць на этыя на свае нокцікі і казаць: «Адамава цела, да мяне нічыё ні дзела». I бальшым пальцам правадзіць па нагцях. Вот дзьве рукі ўместа і пальчыкі радам, як гармошка, i бальшым пальцам правадзіць па адной руке па нагцям і па втарой і сказаць 22 .

См. также в тексте заговора с противоположной части Беларуси:

Стой, мая цялушка, Адамава на табе кожа.

Не я цябе берагу, беражэ цябе Божа.

Днём пад сонцам, ноччу пад месяцам.

Зашэптваю загавараваю ад худых рачэй, ад сабачых вачэй.

А ты, змей чарадзейнік, пад тынам стаяў і зубамі скрыгатаў.

I гәтай кароўцы чорнай шарсцінцы порчы не даваў.

Малачка не адбіраў.

Стой, мая цялушачка, хвосцікам абмахніся, рожкамі абчырціся.

У залаты капыт, у шоўкавы хвосцік ${ }^{23}$.

Именно отсылка к библейскому тексту, к мотиву первочеловека сообщает вполне конкретному ритуальному действию магическую силу влияния на состояние человека.

Предписания смотреть на свои ногти в ситуациях встречи с недоброжелателями широко известны у славян, а также у литовцев. И даже в случаях, когда сам опасаешься взглядом испортить животное, советовали прежде посмотреть на ногти: "O geriausia, tai jei jau kas paprašo palaisc ir in gyvulius reikia aic arba veda parodyc, tai geriausia an savo nagu pažiūrèc ir in viršu, in lubas, kad pirma gyvulio, - ir jau akiu neboja» (Самое лучшее. Если тебя кто попросит посмотреть за животным, или их везут показывать, так самое лучшее посмотреть на ногти, а потом на потолок, прежде чем на животное, тогда уже не сглазишь) (Balkutè 2013: 506).

$\mathrm{y}$ русских не обнаружено фразеологизмов типа адамова кожа, однако «Словарь русских говоров южного Прикамья» сравнение как ноготь 'о твёрдом, бесчувственном' иллюстрирует именно отсылкой к рассмотренному сюжету: «А раз они не послушались, а тело было как ноготь, панцирь, не было у них чувства, хоть и были они муж и жена, у них не было чувства для греха, они святые были» (Подюков 2012: 192). Соотнесение ногтей и одежды проявляется в литовском поверье, согласно которому цветение ногтей указывает на то, что у человека не хватает чего-либо из одежды (Basanavičius 2004: 364). 
В различных еврейских источниках также встречается представление о коже Адама и Евы, похожей на рог, или птичий коготь, или на ногти (Б.Р. 20:12, Пиркей де рабби Элиезер 14, Таргум Псевдо-Ионатана 3:7). Во время обряда Хавдалы (отделении субботы от остальных дней недели) принято смотреть на отблеск света на ногтях пальцев. Если представить, что славянская традиция донесла до нас осколок еврейского предания о грехопадении, то станет понятна природа этого обряда. Ведь время исхода субботы как раз и является временем изгнания из рая. Тогда ясно, почему в это время нужно смотреть на ногти, вспоминая Адама. Такое предположение можно подтвердить и тем фактом, что большинство записей этого фольклорного сюжета в славянской традиции были сделаны в местах длительного исторического совместного проживания евреев и славян (Каспина).

В паремиологии отсылки к народно-библейскому прецеденту усиливают семантику фразеологизмов, наполняют ее особой выразительностью - с ноготкол разг. устар. 'о практичном, твердом, обладающем сильным характером человеке’ (Мокиенко \& Никитина 2007: 444).

Таким образом, мотив ногтей в рассмотренном комплексе выявляет прямые отсылки к библейской истории, что в значительной степени легитимизирует соответствующие выражения и верования. Вместе с тем эти же самые ногти выступают как довольно частотный компонент соматической фрразеологии в целом и даже приобретают характер эталонности. Так, согласно выводам И.В. Захаренко, «в образе фрразеологизма до кониа [кончиков] ногтей 1 в значении 'весь, целиком' кончики ногтей условно описывают границу внутреннего пространства человека и символически выступают как предел проявления во внешних признаках его психологического, чувственно-эмоционального состояния (на что указывает предлог до, обозначающий достижение предела). В то же время ногти предстают как одна из самых маленьких по размеру частей тела и 'измеряют' интенсивность проявления (целиком, до самого малого) внутренних ощущений человека. Фразеологизм в целом выступает в роли эталона, т.е. меры, полноты проявления психологического, чувственно-эмоционального состояния человека. В образе фразеологизма до конца [кончиков] ногтей 2 (в значении 'всем своим существом'; 'самый настоящий, убежденный') человеческое 'Я' выступает как 
мысленно-чувственное 'Я', проявляющееся во внешнем мире в деятельности человека. В данной метафоре кончики ногтей выступают мерой проявления свойств человека, его вкусов, пристрастий и предпочтений. Фразеологизм в целом выступает в роли эталона, т.е. меры, абсолютной убежденности в приверженности кого-л. определенным идеалам, взглядам, образу жизни, стереотипам культуры и под.» (Захаренко 2013: 18).

Такое особое внимание к кончикам ногтей отсылает к еще одному любопытному блоку славянской фразеологии, а именно к праславянскому сочетанию *с̌ъrno podz nogztemz. Н. И. Толстой анализирует это выражение в одной из своих программных статей, приводя пространный набор белорусских и иных фрразеологизмов с общей семантикой 'ничтожно мало, нисколько' - на чарный пазур, бядь тэй на сіні ногиік, не бьло нічога й ні на сіні пазногащь, на сіні кіпещь и др. Украинский карпатский материал выявляет то же значение 'ничтожно мало', однако кроме цветового обозначения содержащегося за ногтем (як за нігтьом чорне/сине) вводит конкретизаторы - йак за ніхтёл болота, йек за ніхтел грэзюкі; йа ни винен $i$ чорного за ніхтел 'я абсолютно не виновен'. Полно и разнообразно представлен разбираемый фрразеологизм в западнославянских языках - польском, кашубском, чешском и словацком. Значение 'ничего, ничтожно мало' реализуется посредством указания на то содержимое, что может вместиться под ногтем и представлено словами *с̌rъno, *sine, *bolto, *brudъ, *kalъ, * gręzь (Толстой 1995: 390-398). См. укр. Стількі зеллі мають, як за нігтллі (ФСУМ 2003: 435).

Образ черноты под ногтем в значении ничтожно малого количества встречается и в эстонском языке - kü̈̈ne võrra / kü̈̈nemusta võrra - букв. грязь под ногтями 'ничего, ничтожно мало', 'скупой человек'; tema silmis ei ole see kü̈̈nemustagi väärt 'в его глазах это и вот столько не значит' (Krikmann).

В. М. Мокиенко в докладе «Н. И. Толстой и славянская историческая фразеология», расширив круг диалектного и языкового материала, который демонстрирует ассоциативную связь ногтя с представлением о малом, незначительном количестве, основное внимание уделяет выражению узнать подноготную (Мокиенко 2003). С семы количества акцент перемещается на сему извлечения чего-то важного, добывания необходимого. К примеру, белорусское выражение за пад ногия хацела б дастаць 'интересуется' (Federowski 1935: 204) возникло, видимо, 
из первоначального 'хотела бы добраться до самой малости, до мельчайших подробностей, подобное значение у болгарского познавал му и черното под ногтите (Толстой 1995: 394), см. также бел. 3-пад ногия выкалупываць 'доставать, приобретать с трудом’ - «Не буду я ім прыборы з-пад ногця выкалупываць, няхай самі думаюць, як на свеце жыць» (Юрчанка 2002: 119), пол. $z$ pod pazura wydobyć 'wyrwać tajemnicę' с пометой «Usł. z Litwy» (Karłowicz и др. 1908: 64), укр. як з-під нігтя виковирюе 'скупо, неохото рассказывает' (Юрченко \& Івченко 1993: 101), бел. у яго с-пад ногия гразі ня дастаняш 'о скупом' (Шатэрнік 1929: 178), нем. jemandem das Schwarze unter den Nägeln nicht gönnеп 'то же'.

В. М. Мокиенко подчеркивает форму «исконного» среднего рода - подноготное, которую реконструирует Н. И. Толстой как первичную для этимологической интерпретации фрразеологизма. Всё подноготное узнает в этом контексте приближается к праславянскому чёрное под ногтел или уйгурскому "выискивать грязь под ногтем» и в то же время свидетельствует, что народно-этимологическое сопряжение с «подлинной» правдой в это время эксплицировалось соединением выражения с наречием подлинно. Между прочим, представление о «подноготности» как «черноте под ногтем» отражается и в современных каламбурных обыгрываниях выражения. Так, в студенческом каламбуре всю подноготную знает никто иной, как ...маникюрша (Мокиенко 2003).

Обращает на себя внимание и такой нюанс значения, как 'дать/ отдать это содержимое из-под ногтя' - слов. Dal bi mu i to blato spoza nechtov, болг. Давал и калта подноктите си (Толстой 1995: 393).

Наглядно убеждаясь, что значение 'мало' и в самом деле можно передать через зрительный образ содержащегося под ногтем, сложно себе представить реальные ситуации, когда кто-то делился бы с ближним этим самым содержимым. И кому это содержимое могло бы понадобиться. Видимо, было бы неправомерно напрямую искать мифологические, и уж тем более библейские истоки данным выражениям. Не ставя целью сводить происхождение этих фрразеологизмов к фольклорному сюжету, тем не менее заманчиво проследить, как этот яркий праславянский образ оказался задействованным в сфере народных рассказов, в данном случае антропогонического и - шире космогонического характера. 


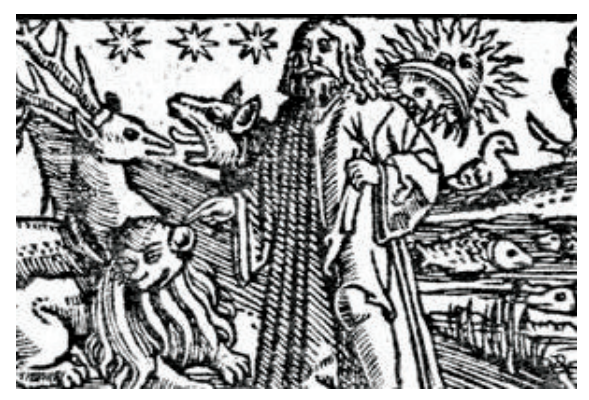

Бог. Гравюра Франциска Скорины.

Если и в самом деле предполагать отсутствие у первых людей, а вероятнее всего богов и демонов одежд и, соответственно, карманов, то реально тем местом, где что-то можно утаить или же просто упрятать и перенести откуда-то, оказываются рот и те же ногти. Обратимся к народным повествованиям о временах первотворения. Основной частью легенды о дуалистическом миросоздании, ее организующим началом, является эпизод о творении суши. Он включает в себя рассказ о нырянии на дно моря за материалом для творения и описание самого творения суши из принесенного со дна моря материала. Безусловно, универсальный материал для творения суши в легендах - земля (ее частица), однако необычайно популярно, точнее сказать, регулярно уточнение - это та земля, что осталась ... за ногтем или же у самого Творца, или у его противника.

укр. І выньіс тьілько за пазурами глины (опов. показує) і тото Бог вышкрептаў шпилькоў. Може того было тьілько гі біб. I Пан Біх тото поблагословиў і зробило сьа куснік земльі (Гнатюк 1902: 5), дрібочку того чорного, що за нїхтем (Гнатюк 1902: 14).

pус. Опускайся ты, лукавый, - сказал Господи, - на самое дно моря, достань ты, лукавый, горсть земли; вынырнул - глядь всю землю водой размыло. ... Опустился лукавый в третий раз и, по Божьему веленью, осталась за ногтем песчиночка. Бог взял ту песчиночку и насеял всю землю, с травами, со всякими для человека угодьями (Белова \& Кабакова 2014: 34-35, № 8. Орл.), Бог и говорит Сатанаилу: «Нырни в морё и достань земли». 
Сатанаил говорит: «Как же я достану, в чём?» - «А ты хоть под ногтём принеси» (Белова \& Кабакова 2014: 34-35, № 11. Урал), ...водой все и вымоет, только под ногтями осталось немного (Белова \& Кабакова 2014: 38. Томск.)

польск. Wyszedł i tylko za paznokciami miał troche ziemi. Бог это положил на поверхность воды и образовалась такая галочка земли. Антогонист хотел утопить Бога и сдвигал его в разные стороны, земля распространялась вместе с ними (Zowczak 2013: 80); ...A ten diabeł nabrał tego piasku za paznokcie $i w$ usta... (Zowczak 2013: 82).

болг. Едно време събрал малко земничка, остъргал изподи нехтете си Бог, плювнал и със слюнката си напраил кал. Напраил мъж и жена (Бадаланова 1994: 8). В записи из бессарабской деревни Бог собрал немного пыли у себя из-под ногтей, плюнул в нее и сделал глину, из которой и вылепил людей. Дяволо с Госпудь кокото дружили, то дявола се иска да победи Госпудь, да остане той... Праили там земята, салял Госпудь едно топченце - от нехтете си там изстъргал едно топченце и фърлил удата. И тя расте (Badalanova 2010: 36).

лит. Бог извлек из-под ногтей черта и из этой земли сотворил остров (Кербелите 2001: 53). Dievas norejo sutverti žemę ir prašè Liuciaus iš vandenu smilčiu parnešti. Liukius iškèlè smilčių: nuo vieno nago Dievui atidave, nuo kito sau i dantis susipulè. Dievas pabarstè smiltis ant vandens ir atsirado žemè. O Liuciui smiltys pradèjo dantyse pūstis. Jis spjovūè jas ir atsirado pekla (Basanavičius 2004: 291) (Бог хотел создать землю и попросил Люцифера принести из воды песка. Люцифер принес песок: изпод одного ногтя отдал Богу, из-под другого высыпал себе в рот. Бог высыпал песок на воду, и появилась земля. А во рту Люцифера начал разрастаться. Он выплюнул их и появилось пекло).

Также в этиологических легендах встречается указание и на то, что из утаенной под ногтями черта земли образуются змеи: раз дал Бог лукавому щепотку земли и велел ему, чтоб он на пустое место бросил, лукавый как бросил ту «зымлычку», - из нее образовалась та земля,

на яки оце мы жывем. Лукавый ны забув и соби заховаты зымлычки за ногти з тии пучки, шо Бог ёму дав: лукавый, бач, думав другу соби землю сотворыты. И як одийшов от Бога, выдрянав 3-пид ногтив порошынки зымли и бросыв их на пространство. Но 3 того праху ны получылось зымли, а сталы з нёго гадюкы, жабы и вси нычысти жывотни (Харьк., цит. по Кузнецова 1998: 67). 
Крайне любопытно и то, что змеи в этиологических легендах появляются не только из земли за ногтями, но и из стружек из мешка любопытного Адама. Адам был превращен в аиста и вынужден собирать змей, а «як вызбіраеш, то зноў будзеш чалавекам»:

Чорт, стругаючы воўка, нарабіў многа стружак, так Бог іх пазбіраў, насыпаў у мяшок, завязаў і даў Адаму, каб занёс і ў рэку ўкінуў, анно каб не разверчуваў. Адам узяў і панёс. Ужэ каля ракі цікавасць яго ўзяла: што там такое? Так не вытрываў. Калі развяжа мяшок, ажно стуль жабаў, верацяніцаў, яшчырацаў, вужоў як высыплецца! Адам чыста спалохаўся і пабег назад. А Бог гәта ўсё бачыў, так перамяніў яго ў бусла і кажа: «Датуль будзеш іх збіраць, пакуль усё не вызбіраеш, а як вызбіраеш, то зноў будзеш чалавекам» (Federowski 1897: 176-177).

Обрезанные ногти запрещалось разбрасывать, иначе после смерти душа не сможет попасть ни в рай, ни в ад, т.к. силы и неба, и ада заставят их собирать. Согласно западно-белорусской легенде, по воле Бога душа человека, разбрасывавшего при жизни ногти, ходит в виде аиста, пока не соберет их, а когда соберет, то вновь обращается в человека и идет в небо: «Каторы чалавек пазуры абрэзывае і кідае на землю, то па смерці душа его ні да пекла ні ідзе, ні да неба, адно з волі Бога ходзіць буслам, пакуль усіх пазуроў ні вызьбірае», «Як бусел вызбірае ўсе свае пазуры, то робіцца чалавекам і ідзе проста да неба, бо ўжэ яго пакута скончылася» (Federowski 1897: 221,185).

Данные записи дают основание для ряда выводов:

ногти и грязь из-под ногтей выступают в одном ряду со змеями и ужами (полученными к тому же из стружек черта); «первые» разбросанные ногти собирает Адам;

собрав ногти, у человека «сканчаюцца пакуты», см. библейские аллюзии.

Таким образом, ногти за жизнь человека словно бы отрастают настолько, чтобы вернуть утраченную первоначальную «роговую» оболочку, без которой невозможно возвращение человека в «небо». Человек перед отправлением в вечность уподобляется Адаму до грехопадения. Р. Томицкий обратил внимание на болгарскую легенду, в которой роговая кожа первых людей уравнивалась с кожей ужа (см. бел. Адама-аиста) и тогда «наличие ее в раю и утрата по изгнанию означала бы 
один из аспектов очеловечивания - утрату бессмертия. Это очевидно в контексте символики ужа, который, меняя линовило, омолаживается, а также в контексте символики «возрождения» у ногтей. Таким образом, самым большим наказанием за непослушание было отнятие у прародителей вечной жизни» (Tomicki 1976: 90).

Именно отсылка к сюжету об упрятанной земле за ногтями объясняет требование регулярно обрезать ногти: «Как полез, то теперь уж принес, да только за ногтяли (вот тут-то и говорят, что надо ногти обрезать) вытрусил. Бог взял его и посеял по морю, и сделалась густота, после оказалась вот и зелля» (Белова \& Кабакова 2014: 35-36. Тверс.).

Такая завидная регулярность упоминания данной детали (принесения земли за ногтями), причем в разных славянских традициях (как восточно-, так и южно- и западнославянских), литовских легендах подчеркивает ее неслучайный характер и косвенно указывает на особый статус ногтей и содержимого за ними. При единичном упоминании использования для миротворения земли из-под ногтей у Бога абсолютное преимущество за текстами, где эту самую землю прячет у себя под ногтями его противник - черт. Т.е. это то, что кто-либо прячет из корыстных, нечистых побуждений. В этом контексте напрашиваются приведенные Н. И. Толстым выражения Každý ma čierne za nechtom, Každý ma za nechtami blato, где количественная оценка «черного» или «грязи» под ногтем заменяется оценкой экспрессивно-качественной: «черное» или «грязь» (плохое) - у каждого есть немного черного (грязи) под ногтем, т.е. вероятно у каждого есть немного (недостатков, грехов) (Толстой 1995: 393). Понимая всю дистанцию, тем не менее хочется упомянуть новг. узнать по ногтял 'легко узнать кого-л. по какому-л. признаку' (НОC 6: 35) и болг. Отрежи му ноктьето, докле е лладо (Геров 3: 280) 'о формировании человеческого характера'.

Хорватское же выражение crno ispod nokta со значением 'все до последней капли’ (Menac-Mihalić 2005: 247) целиком соотносится с описанными контекстами. Демонологические аллюзии у черноты под ногтем угадываются в немецких наименованиях маленького лесного демона, который вызывает болезнь ногтей, - blaue Nägel (Höfler 1899: 432). В псковских диалектах синий ноготь 'прозвище худого больного ребенка' (Мокиенко \& Никитина 2007: 444). 
Белорусская народная космо- и антропогония свидетельствуют о знании библейского текста, однако чаще демонстрирует его фольклорные адаптации и комментирование в русле традиционных воззрений и морали. Кроме того, органичное переплетение библейских реплик с архаическими мифологическими схемами обусловливает ряд магических, народномедицинских, обрядовых практик. Ряд устойчивых выражений в контексте легенд выявляет также новые и неочевидные для обыденного взгляда оттенки смысла.

\section{Примечания}

1 Krikmann Arvo. Eesti lühivormide allikaloost 3. Kirikukirjandus. http:// www.folklore.ee/ kriku/ALLIK/allik3.htm.

${ }^{2}$ И. Носович приводит и еще одно устойчивое выражение с упоминанием Адама и аллюзией к библейским событиям: «Адамова костка 'подкожный костеобразный нарост на теле. У русинов есть поверье, что такие наросты исцеляются только прикосновением к телу мертвеца» (Носович 1870: 3).

3 Зап. Боганева Е. М. в 2004 г. в д. Слободка Октябрьского р-на Гомельской обл. от Ламахи В. И., 1942 г.р.

${ }^{4}$ В народнобиблейских легендах имя Христа нередко используется вместо называния Бога.

5 Зап. автором в 2007 г. в д. Подрезы Чашникского р-на Витебской обл. от Песецкой В. П., 1931 г.р.

6 Особенно популярны были сюжеты о творении мира и первого человека (см. апокрифы «О крестном древе», «О Тивериадском море», «Беседа трёх святителей» и др.).

7 Архив Могилевского госпедуниверситета: зап. Лебедева М. в д. Хвойница Кировского р-на Могилевской обл. от Калиновой А. И., 69 лет.

8 Архив Могилевского госпедуниверситета: зап. в 2000 г. Расторгуева Н. в д. Прусино Костюковичского р-на Могилевской обл. от Ильенковой Л. А., 1927 г.р.

9 Зап. в 2010 г. Володина Т., Андрюнина М. и Антропов Н. в д. Щитковичи Стародорожского р-на Минской обл. от Стром Ф. М., 1924 г.р. 
10 Зап. Володина Т. и Кухаронак Т. в 2011 г. в д. Липляны Лельчицкого р-на Гомельской обл. от Лось А. П., 1929 г.р.

11 Зап. в 2010 г. Володина Т. и Кухаронак Т. в д. Прачомушки Ельского района Гомельской обл. от внучки Ецухна И. Ф., 1900 г.р.

12 Зап. в 2010 г. Володина Т. и Кухаронак Т. в д. Переровский Млынок Житковичского р-на Гомельской обл. от Швед Надежды Адамовны.

${ }^{13}$ Особенно популярны были сюжеты о творении мира и первого человека (см. апокрифы «О крестном древе», «О Тивериадском море», «Беседа трёх святителей» и др.).

${ }^{14}$ См. прежде всего работы М. Каспиной.

${ }^{15} \mathrm{~B}$ болгарском фольклоре можно найти похожий мотив о творении женщины из хвоста чёрта. Тот же сюжет известен и на Украине.

${ }^{16}$ Архив С. Сахарова. Latviešu folkloras krātuve (LFK), с. 205. Зап. в 1928 г. Н. Талерко в д. Придруйщина Даугавпилского р-на от деда Михася.

17 Зап. в 2006 г. Боганева Е. и Володина Т. в д. Сталюги Лепельского p-на Витебской обл. от Кузьмич С. П., 1934 г.р.

18 Зап. в 2008 г. Володина Т. и Лобач В. в д. Бояры Борисовского р-на Минской обл. от Антоновой Е. А., 1928 г.р.

19 Зап. в 2009 г. Валодина Т. в д. Барсуки Кармянского р-на Гомельской обл. от Кротовой Ж. А., 1959 г.р.

20 Фольклорный архив Литературного музея Эстонской академии наук в Тарту: ERA II 163, 82/4 (19) < Setu, Järvesuu v., Värska k. - Nikolai Ress < Aleksei Mägioja, 62 a. (1937).

21 Зап. в 2005 г. Боганева Е. в д. Чкалово (Жеребное) Гомельского р-на от Сухоцкой У. И., 1927 г.р.

22 Зап. в 2012 г. Боганева Е. и Володина Т. в д. Мошевое Костюковичского р-на Могилевской обл. от Кабанцовой Раисы Николаевны, 1939 г.р. На Гродненщине чтоб не сглазить новорожденного, прикусывали ногти на руке и, глядя на дитя, приговаривали: «Зашкодзь маім пазногцям, але не гэтаму дзіцяці» (Васілевіч \& Салавей 2009: 50).

${ }^{23}$ Архив отдела фольклористики Центра исследований белорусской культуры, языка и литературы НАНБ: зап. Игнатенко С. в 1968 г. в д. Красное Лидского р-на Гродненской обл. от Калодка С. Г., 1879 г.p. 


\section{Литература}

Badalanova Geller, F. 2010. Gynesis in Genesis. Forma formens. Studi in onore di Boris Uspensky. Napoli, cc. 17-48.

Balkutè, R. 2013. Galia užburti (kenkimo magija 1982-2012 metu irašuose). Vilnius.

Basanavičius $2004=$ Basanavičiaus tautosakos biblioteka 2004. Juodoji knyga. Surinko Jonas Basanavičius. Sudarè Kostas Aleksynas. Parengè Kostas Aleksynas, Leonardas Sauka. Ivadą ir paaiškinimus parašè Leonardas Sauka t. 12. Vilnius: Lietuvių literatūros ir tautosakos institutas.

Dahnhardt, O. 1907. Natursagen. Eine Sammlung Naturdentender Sagen, Marchen, Fabeln und Legenden, bd. 1, Sagen zum Alten Testament. Leipzig und Berlin.

Federowski, M. 1897. Lud białoruski na Rusi Litewskiej. Materiały do etnografii stowiańskiej zgromadzone $w$ latach 1877-1905: $w 8 t$. T. 1. Kraków: Wydawnictwo Komisji Antropologicznej Akademii Umiejętności.

Federowski, M. 1935. Lud białoruski na Rusi Litewskiej: Materiały do etnografii stowianskiej zgromadzone w latach 1877-1905: w 8 t. T. 4. Przysłowia, żarciki, wyrażenia stałe oraz zagadki ludu, mieszczan i zagrodowców z okolic Grodna, Sokółki ... Warszawa: T-wo nauk. Warszawskie.

Fischer, A. 1909. Uzupełnienie Dahnhardta. Lud XV, cc. 320-339.

Höfler, M. 1899. Deutsches Krankheitsnamen-Buch. München: Verlag von Piloty.

Karłowicz J. \& Kryński A. \& Niedźwiedzki W. 1908. Stownik języka polskiego, T. III. N-O. Warszawa: Nakł. prenumeratorów i Kasy im. Mianowskiego.

Kluge F. 1899. Etymologisches Wörterbuch der deutschen Sprache. Strassburg: Karl Trübner.

Krikmann, A. Krikmann Arvo. Eesti lühivormide allikaloost. http://www. folklore.ee/ kriku/ALLIK/allik3.htm. 
Menac-Mihalić, M. 2005. Frazeologija novoštokavskih I kavskih govora u Hrvatskoj: s rječnicom frazema $i$ značenjskim kazalom s popisom sinonimnih frazema. Zagreb: Školska knjiga.

Tomicki, R. 1976. Słowiański mit kosmogoniczny. Etnografia Polska XX (2), cc. $47-97$.

Walter, H. \& Mokienko, V. M. 2009. Deutsche-russisches Wörterbuch biblischer Phraseologismen. Mit historisch-etymologischen Kommentaren. Greifswald: Ernst-Moritz-Arndt-Universität Greifswald. Philosophische Fakultät.

Zowczak, M. 2013. Biblia ludowa. Interpretacje watków biblijnych w kulturze ludowej. Torun: Wydawnictwo naukowe uniwersytetu Mikolaja Kopernika.

Бадаланова, Ф. 1994. Biblia Folklorica. Фолклорна конфесионална конвенщия на българите в Бесарабия и Таврия. Български фболклор. Cogбus 1, cc. 5-21.

Белова, О. В. 2004. Народная Библия: Восточнославянские этиологические легендь. Москва: Индрик.

Белова, О. В. \& Кабакова, Г. И. 2014. У истоков мира: Русские этиологические сказки и легенды. Москва: ФОРУМ; НЕОЛИТ.

Вархол, Н. \& Івченко, А. 1990. Фразеологічний словник левківських говірок східної Словаччини. Братіслава: Словацьке педагогічне вид-во.

Васілевіч, У. А. \& Салавей, Л. М. 2009. Замовы. Мінск: Беларусь.

Геров, Н. 1899. Речник на българския език с тълкуване речите на български и руски, Ч. 3. Л-О. Пловдив: Съгласие.

Гнатюк, В. 1902. Галицько-руські народнї легенди Т. II. Етнографбічний збірник XIII. Львів.

Григорьев, А. В. 2006. Русская библейская фбразеология в контексте культуры. Москва: Индрик.

Добровольский, В. Н. 1891. Смоленский этнографический сборник: вып. 1. Москва.

Захаренко, И. В. 2013. Архетипическая оппозиция 'свой п̃ чужой' в пространственном коде культуры. М. Л. Ковшова \& В. В. Красных 
\& А. И. Изотов \& И. В. Зыкова (ред.). Язык, сознание, колмуникаиия. Москва: МАКС Пресс, сс. 15-31.

Кабакова, Г. И. 2001. Антропология женского тела в славянской традииии. Москва: Ладомир.

Каспина, М. М. Сюжеть об Адаме и Еве в свете исторической поэтики. http://www.ruthenia.ru/folklore/caspina2.htm (дата обращения 29.11.2007).

Кербелите, Б. 2001. Типы народных сказаний. Структурно-селантическая классификаиия литовских этиологических, мифбологических сказаний и преданий. СПб.: Европейский дом.

Кузнецова, В. С. 1998. Дуалистические легенды о сотворении мира в восточнославянской больклорной традиции. Новосибирск: Издательство СО РАН НИЦ ОИГГМ.

Левкиевская, Е. Е. 2004. Ногти. Н. И. Толстой (ред.). Славянские древности. Этнолингвистический словарь. Т. 3. К (Круг) П (Перепелка). Москва: Международные отношения, сс. 427-429.

Мокиенко, В. М. 1998. Адам в славянских языках. А. А. Киклевич (ред.). Число-язык-текст. Сб. статей к 70-летию Адала Евгеньевича Супруна. Минск: Белгосуниверситет, сс. 14-28.

Мокиенко, В. М. 2003. Никита Ильич Толстой и славянская историческая фразеология. Праблемы уусхонеславянскай этналінгвістькі. Матэрыяль міжнароднай навуковай канфбырэниььі (Мінск, 24-26 красавіка, 2003 года). Мінск: VII «Тәхнапрынт», сс. 23-34.

Мокиенко, В. М. 2013. Библеизмы в европейской фразеологии и паремиологии. H. Walter \& V. Mokienko \& D. Baláková (ред.). Die slawische Phraseologie und die Bibel - Славянская фрразеология и Библия - Slovanská frazeológia a Biblia. Greifswald: Ernst-MoritzArndt-Universität Greifswald, cc. 144-153.

Мокиенко, В. М. \& Никитина, Т. Г. 2007. Большой словарь русских поговорок. Москва: Олма Медиа Групп.

НОС 2010. Новгородский областной словарь. Санкт-Петербург: Наука.

Носович, И. И. 1870. Словарь белорусского наречия. СПб: Типография Імператорской Академии наук.

Подюков, И. А. 2012. Словарь русских говоров Южного Прикалья. Вып. 2. Пермь, изд-во ПГГПУ. 
Родионова, И. В. 2000. Илена библейско-христианской традищии в русских народных говорах. Дис. ... филол. наук. Спец. 10.02.01 русский язык. Екатеринбург: УрГУ.

Сержпутоўскі, А. 1998. Прылихі і забабоны беларусаў-палешукоў. Мінск: Універсітэцкае.

Толстая, С. М. 1998. О нескольких ветхозаветных мотивах в славянской народной традиции. От Бытия к Исходу. Отражение библейских сюжетов в славянской и еврейской народной культуре. Сборник статей. Москва: ГЕОС, сс. 21-37.

Толстой, Н. И. 1995. Язык и народная культура: Очерки по славянской мифбологии и этнолингвистике. Москва: Индрик.

ФСУМ 1993. Фразеологічний словник украйнськой мови. Г. М. Удовиченко. Кн. 1-2. Київ: Наукова думка.

Шатэрнік, Н. 1929. Краёвы слоўнік Чэрвеншчыны. Менск: Інстытут беларускай культуры.

Юрчанка, Г. Ф. 2002. Народнае мудраслоўе: Слоўнік. Мінск: Бел. навука.

Юрченко, О. С. \& Івченко, А. О. 1993. Словник стійких народних порівнянь. Харків: Основа.

\section{Summary}

\section{Phraseology and Magical Practices in the Context of Anthropo- and Cosmogenic Legends (Belarusian Tradition at the European Background)}

\section{Tatsiana Valodzina}

Keywords: anthropogony, charms, cosmogony, legends, Belarusian folklore, biblical aphorisms, folk Bible, folk medicine, phraseology

For the past two centuries, anthropogonic legends have remained one of the foci of European folkloristics. The general body of motifs has been studied extensively; scholars have drawn parallels between archaic and biblical elements and described particular plots and characters. However, every ethnic tradition contributes its own, often unique variants to the universal tradition. Not only do these variants enrich the complex whole, but they 


\section{ТАтьяна ВолодинА}

also allow us to see the familiar from a new perspective, reconstruct the roots of a legend more deeply, and offer insights into its current state. After more than a half-century's neglect of the subject, recent field notes taken in Belarus demonstrate the richness of anthopogonic folklore, revealing new plots and details. Folk-biblical plots have become the background against which linguistic idioms, charms, and folk medicine beliefs have evolved. This paper discusses such folk motifs as Eve's creation from Adam's tail or the cornified skin of protoplasts, and the antagonist hiding soil under its fingernails, as well as the paremiological representation of these motifs. 


\section{МИССИЯ ВЫПОЛНИМА Перспективы изучения фольклора}

http://www.folklore.ee/rl/pubte/ee/sator/sator19/

ISSN 1736-0323

ISBN 978-9949-586-60-8

DOI: $10.7592 /$ Sator.2018.19

Тарту 2018

Редакторы-составители выпуска:

Маре Кыйва \& Татьяна Володина

Редактор серии: Маре Кыйва

Фото: Яак Кикас, 2018 «Осень в Тарту»

Оформление обложки: Лииса Весик

Верстка \& HTML: Диана Кахре

Печатное издание: МИССИЯ ВЫПОЛНИМА:

Перспективы изучения фольклора. SATOR 19. Тарту 2018

Публикация книги осуществлена совместно Эстонским литературным музеем и Центром исследований белорусской культуры, языка и лит ерат уры Националь ной акад емии наук Б еларус и, п ри поддержке Министерства образования и науки Эстонии (IUT 22-5), Фонда регионального развития ЕС (ТK 145, Центр компетенции по Эстонским исследованиям); при поддержке проекта, финансируемого Министерством иностранных дел Эстонии из бюджета по сотрудничеству и развитию, Эстонской Академией Наук и Национальной академии наук Беларуси.

Оформление электронного издания осуществлено при поддержке проекта ЕККМ14-344 “Расширение областей применения и представление эстонского языка, культуры и фольклора в электронных информационных средствах".

() Эстонский литературный музей

(c) Авторы

(с) Яак Кикас 